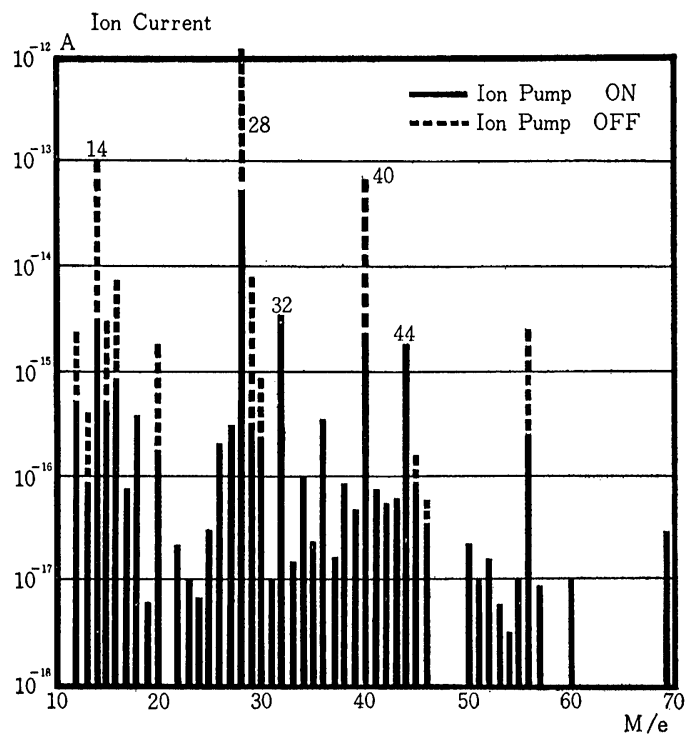

Fig. 8. Spectrum of residual gases.

およびわずかの 15,16 であり，その他の成分は全くみ とめられない。二次電子增倍管を用いて分析すると

Fig. 8 のように他の成分もかなり多いことがわかる。 上記 $\mathrm{N}_{2}, \mathrm{CO}, \mathrm{Ar}, \mathrm{CH}_{4}, \mathrm{CO}_{2}$ のほかに $\mathrm{H}_{2} \mathrm{O}$ と $\mathrm{C}_{1}$, $\mathrm{C}_{2}, \mathrm{C}_{3}, \mathrm{C}_{4}$ グループの炭化水菜がみとめられた。 オンポンプを停止すると残留ガス性增大するが, $\mathrm{N}_{2}$, $\mathrm{Ar}, \mathrm{CH}_{4}$ のピークの増加は顕著であり, 他の炭化水 菜， $\mathrm{H}_{2} \mathrm{O}$ などはあまり增加しない。一般的にわれわ れの分析計は炭化水素の成分が少なく微量ガス分析用
として有利であるが，これはイオンポンプを使用した ためといらよりもむしろ完全にベークアウトできるた めであると考えられる。

\section{6.むす び}

实験中の超高真空質量分析計について構造の大夏と 实験結果の一部を説明した。今後検討すべき問題点と して,

（1）ガスケット部分を改良してリークを $1 \times 10^{-9} \mathrm{cc} /$ $\sec$ 以下とする。

（2）コンダクタンスの大きい金属バルブを製作するこ と。以上の点は現在改造中である。さらに

（3）二次電子增倍管の電極処理法を検刢し，利得を高 めること。

（4）実際に ppm の桁の微量不純物を分析して性能を 検討すること。 などの点については今後も研究をつづけたい。

現状で $10^{-9} \mathrm{mmHg}$ の桁で一般ガス分析に用い得る こと拉よび $10^{-6} \sim 10^{-7} \mathrm{mmHg}$ の桁で静作怔分析が行 えることが一応たしかめられている。

\section{文献}

1) 後藤他, 質量分析, No. 14, 21 (1960).

2) 川崎他, 具空, 3, No. 3, 10 (1960).

3) 道岛 - 後藤, 質量分析, No. 15, 26 (1960).

4) 岡野·後藤・緒方, 質量分析, No. 16, 20 (1960).

5) 著者, M. D. L. R., 2, No. 1, 71 (1960).

\title{
On the Defect of Peak Shape in Mass Spectrum
}

\author{
Nozomu Morito and Hitoshi Tsuyama*
}

(Received July 28, 1961)

\begin{abstract}
This paper describes the calculation of the deformed peak shape in mass spectrum.
Sometimes the top of the peak in mass spectrum is inclined and a swelling appears on the skirt of the peak. Assuming that a main ion beam accompanied with a weak beam enters into an ion collector, the deformed peak shape can be expected from calculation.
\end{abstract}

\section{Introduction}

Peaks in mass spectrum normally have flat tops

* Hitachi Central Research Laboratory, Kokubunji, Tokyo, Japan. parallel to the base line, but sometimes the top is inclined and a swelling appears on the skirt of the peak as the right peak in Fig. 1. Though the complete explanation of this phenomenon is difficult 
and remains to be further studied, the deformed peak shape similar to that shown in Fig. 1 is expectable when a main ion beam accompanied with a weak beam enters into the ion collector. The peak shape in case of double-beam is calculated in this paper.

\section{Calculation of peak shape}

The intensity distribution of a normal ion beam on the collector slit plane is not definite and a certain assumption is necessary. It is assumed in this paper that the ion beam whose intensity distribution is represented by Gaussian error function is scanned across the collector slit. Then, the peak shape for a single beam is given by

$$
\left.\begin{array}{c}
I=\frac{1}{2}\left\{\phi\left(x+\frac{\lambda}{2}\right)-\phi\left(x-\frac{\lambda}{2}\right)\right\} \\
\phi(\xi)=\frac{2}{\sqrt{ } \pi} \int_{0}^{\xi} e^{-t 2} d t
\end{array}\right\}
$$

where $\lambda$ corresponds to the slit width.

If there are two beams and one of them comes close on the heels of the other, the peak shape to be obtained is given by

$$
\begin{aligned}
& I=\frac{\alpha}{2}\left\{\phi\left(x+\frac{\lambda}{2}\right)-\phi\left(x-\frac{\lambda}{2}\right)\right\} \\
& +\frac{\beta}{2}\left\{\phi\left(x+\frac{\lambda}{2}-s\right)-\phi\left(x-\frac{\lambda}{2}-s\right)\right\}
\end{aligned}
$$

where $s$ is the separation of the beams and $\alpha / \beta$ is their intensity ratio.

Some curves calculated from Eq. (2) are illustrated in Fig. 2. The figure shown in Fig. 2c has a resemblance to the deformed peak in Fig. 1.

\section{Conclusion}

The deformed peak shape as shown in Fig. 1 does not necessarily depend on the double-beam, but the double-beam in some condition is sure to cause such a deformed peak.

The ion optical system of the mass spectrometer is, for example, shown in Fig. 3. Some of ions may be reflected at an edge of a slit and cause one or two subsidiary effective ion sources which produce multiple-beam. Anomalous ions such as metastable ions which enter the collector closely to the main beam in question may be another origin of the deformed peak.

In practice, the deformed peak is observed frequently when there exist metastable ions. The deformed peak also appears in case of wrong adjustment of ion accelerlating system and disappears by the correction of adjustment.

\section{Acknowledgement}

The authors wish to thank Dr. B. Tadano of Hitachi Central Research Laboratory for his helpful discussion and encouragement during this work.

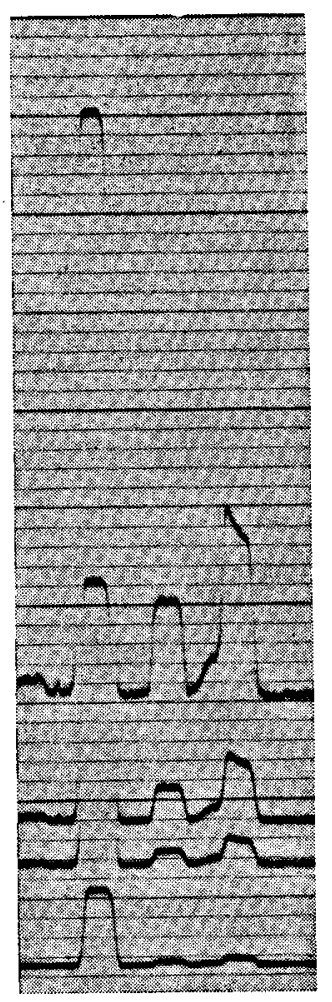

Fig. 1. An example of observed mass spectrum. 

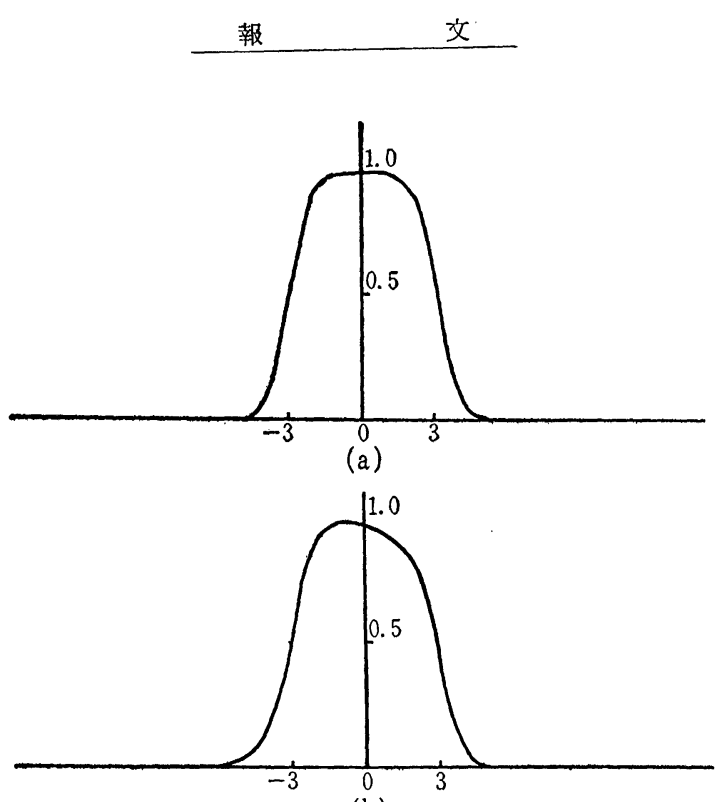

(b)

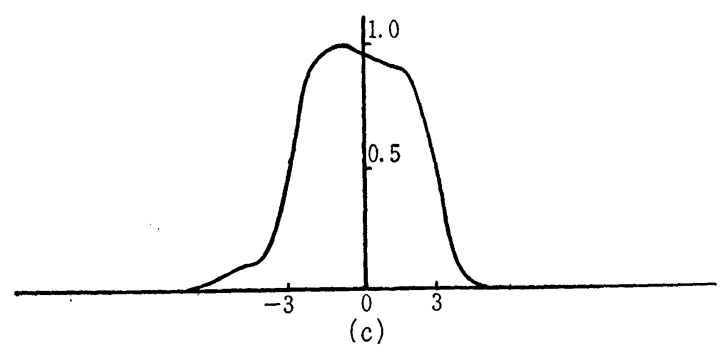

Fig. 2. Calculated peak shape from Eq. 2. $\alpha=0.9, \quad \beta=0.1, \quad \lambda=6$
(a) $s=0$,
(b) $s=-2$,
(c) $s=-3$

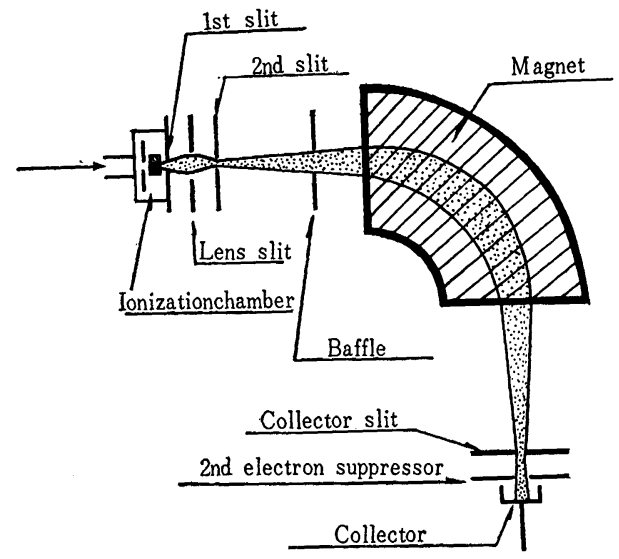

Fig. 3. Schematic diagram of ion optical system in the mass spectrometer.

$$
104-(38)
$$

